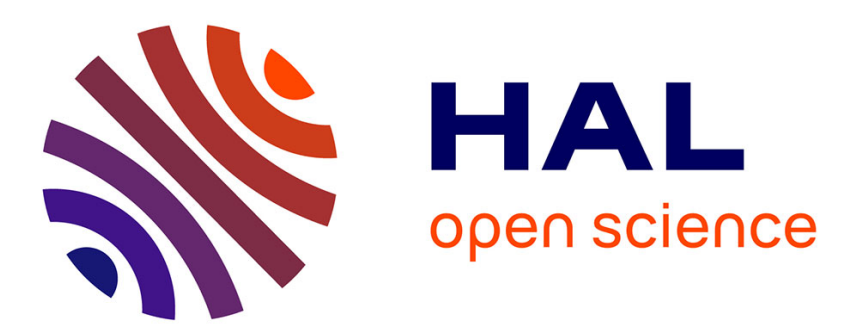

\title{
Effect of Fluorine and Nitrogen Anions on Properties of Ca-Si-Al-O Glasses
}

\author{
Annaik Genson, Amir R. Hanifi, Aurélie Vande Put, Michael J. Pomeroy, \\ Stuart Hampshire
}

\section{> To cite this version:}

Annaik Genson, Amir R. Hanifi, Aurélie Vande Put, Michael J. Pomeroy, Stuart Hampshire. Effect of Fluorine and Nitrogen Anions on Properties of Ca-Si-Al-O Glasses. Materials Science Forum, 2007, 554, pp.31-35. 10.4028/www.scientific.net/MSF.554.31 . hal-02143029

\section{HAL Id: hal-02143029 \\ https://hal.science/hal-02143029}

Submitted on 29 May 2019

HAL is a multi-disciplinary open access archive for the deposit and dissemination of scientific research documents, whether they are published or not. The documents may come from teaching and research institutions in France or abroad, or from public or private research centers.
L'archive ouverte pluridisciplinaire HAL, est destinée au dépôt et à la diffusion de documents scientifiques de niveau recherche, publiés ou non, émanant des établissements d'enseignement et de recherche français ou étrangers, des laboratoires publics ou privés. 


\section{Open Archive Toulouse Archive Ouverte (OATAO)}

OATAO is an open access repository that collects the work of Toulouse researchers and makes it freely available over the web where possible

This is an author's version published in: http://oatao.univ-toulouse.fr/23919

Official URL: https://doi.org/10.4028/www.scientific.net/MSF.554.31

\section{To cite this version:}

Genson, Annaik and Hanifi, Amir R. and Vande Put, Aurélie Michael J. and Hampshire, Stuart Effect of Fluorine and Nitrogen Anions on Properties of Ca-Si-Al-O Glasses. (2007) Materials Science Forum, 554. 31-35. ISSN 1662-9752

Any correspondence concerning this service should be sent to the repository administrator: tech-oatao@listes-diff.inp-toulouse.fr 


\title{
Effect of Fluorine and Nitrogen Anions on Properties of Ca-Si-Al-O Glasses
}

\author{
A. Genson ${ }^{\text {a }}$, A. R. Hanifi ${ }^{b}$, A. V. Put ${ }^{c}$, M. J. Pomeroy ${ }^{d}$, S. Hampshire \\ Materials and Surface Science Institute, University of Limerick, Ireland \\ aannaik.genson@ul.ie, bamir.hanifi@ul.ie, cvande_put@ensil.unilim.fr, dmichael.pomeroy@ul.ie, \\ estuart.hampshire@ul.ie
}

Keywords: Ca-SiAION-F, glass, fluoride, oxyfluoronitride, thermal analysis, mechanical properties

\begin{abstract}
The preparation of bulk glasses in Ca-Si-Al-O-N-F system with the composition in equivalent $\%$ of $28 \mathrm{e} / \mathrm{oCa}: 56 \mathrm{e} / \mathrm{oSi}: 16 \mathrm{e} / \mathrm{oAl}: 100-\mathrm{X}-\mathrm{Ye} / \mathrm{oO}: \mathrm{Xe} / \mathrm{oF}: \mathrm{Ye} / \mathrm{oN}$ are reported. The glass formation behaviour and properties of this new range of glasses are examined in detail. Fluorine decreases the glass transition temperature, the density and the mechanical properties of the glasses while nitrogen increases them. Therefore, it appears that fluorine acts as a network modifier while, on the contrary, nitrogen acts as a network former even in presence of fluorine.
\end{abstract}

\section{Introduction}

Studies have shown that when oxygen is replaced by nitrogen in alumino-silicate glasses, glass transition temperature, elastic modulus and hardness increase linearly with nitrogen content [1-4]. The main conclusion is that $\mathrm{N}$ may be viewed as a network forming anion considering the fact that the effects of nitrogen and modifiers on glass properties are independent [5]. Investigations on the effect of fluorine in alumino-silicate glasses have shown that fluorine reduces the glass transition temperature $[6,7]$ and this anion may be viewed as a network modifying anion. Fluoro-aluminosilicate glasses are mainly used in biomaterials applications as bone substitutes or dental restoratives. The addition of nitrogen could lead to higher mechanical properties for these biomaterials. Shimada et al. [8] made an attempt to prepare a Ca-Si-Al-O-N-F ceramic using a mixture of $\alpha-\mathrm{Si}_{3} \mathrm{~N}_{4}, \mathrm{Al}_{2} \mathrm{O}_{3}$ and $\mathrm{AlN}$ (to form a SiAlON with high $\mathrm{N}$ content) with $\mathrm{CaF}_{2}$. The results from X-ray diffraction suggest that $\mathrm{CaF}_{2}$ did not react with the SiAlON and is stable at this composition at a temperature of $1700^{\circ} \mathrm{C}$ in a closed system under $150 \mathrm{MPa}$ pressure.

In the present work, the formation and stability of glasses in the oxyfluoride (Ca-Si-Al-O-F) and the oxyfluoronitride (Ca-Si-Al-O-N-F) systems have been investigated in order to study the effect on glass formation and thermal and mechanical properties of replacing oxygen by both $\mathrm{F}$ and $\mathrm{N}$.

\section{Experimental Procedures}

Glass synthesis. The starting materials were commercial powders, $\mathrm{CaO}(99.9 \%$ purity, $\mathrm{BDH}$ Chemicals), $\mathrm{SiO}_{2}$ (99.9\% purity, Fluka Chemicals), $\mathrm{Al}_{2} \mathrm{O}_{3}$ (99.995\% purity, Sumitomo Corporation Europe $\mathrm{Ltd}), \mathrm{Si}_{3} \mathrm{~N}_{4}$ (99.9\% purity, UBE) $\mathrm{CaF}_{2}$ (99.9\% purity, Aldrich Chemicals). The chemical compositions are shown in Table 1 in equivalent percent [e/o], which has been explained in previous publications $[1,3,4]$ and in atomic ratios. The equivalent compositions for all Ca-Si-Al-O$\mathrm{N}-\mathrm{F}$ glasses were calculated assuming that $\mathrm{Ca}, \mathrm{Si}, \mathrm{Al}, \mathrm{O}, \mathrm{N}, \mathrm{F}$ were in their "normal" $+2,+4,+3,-2$, $-3,-1$ oxidation states, respectively. The mixed powders were wet ball milled in isopropanol for 24 $\mathrm{h}$, and then dried again. The O-F series described in Table 1 was directly melted in an alumina crucible in air atmosphere at $1470^{\circ} \mathrm{C}$ for $1 \mathrm{~h}$ after which the melts were poured into a graphite mould and annealed. The O-F-N series powders were first isostatically pressed under $150 \mathrm{MPa}$ and then melted at $1740^{\circ} \mathrm{C}$ for $1 \mathrm{~h}$ under $0.1 \mathrm{MPa} \mathrm{N}_{2}$ in a $\mathrm{BN}$-lined graphite crucible to avoid any contamination between the glass and the crucible. Melts were poured into a graphite mould and annealed. After the determination of the glass transition temperature (Tg) by differential thermal 
analysis, both series were annealed in air at $\mathrm{Tg}-50^{\circ} \mathrm{C}$ or $\mathrm{Tg}$ for $1 \mathrm{~h}$ and then cooled slowly to room temperature.

Table 1. Compositions of glasses studied

\begin{tabular}{|c|c|c|c|c|c|c|c|c|c|c|c|c|}
\hline \multirow[t]{2}{*}{$\mathrm{O}-\mathrm{F}$ series } & \multicolumn{6}{|c|}{ Equivalent \% } & \multicolumn{6}{|c|}{ Atomic ratios } \\
\hline & $\mathrm{Ca}$ & $\mathrm{Si}$ & $\mathrm{Al}$ & $\mathrm{O}$ & $\mathrm{F}$ & $\mathrm{N}$ & $\mathrm{Ca}$ & $\mathrm{Si}$ & $\mathrm{Al}$ & $\mathrm{O}$ & $\mathrm{F}$ & $\mathrm{N}$ \\
\hline F0 & 28 & 56 & 16 & 100 & 0 & 0 & 14 & 14 & 5.33 & 50 & 0 & 0 \\
\hline F1 & 28 & 56 & 16 & 99 & 1 & 0 & 14 & 14 & 5.33 & 49.5 & 1 & 0 \\
\hline $\mathrm{F} 2$ & 28 & 56 & 16 & 98 & 2 & 0 & 14 & 14 & 5.33 & 49 & 2 & 0 \\
\hline F3 & 28 & 56 & 16 & 97 & 3 & 0 & 14 & 14 & 5.33 & 48.5 & 3 & 0 \\
\hline F4 & 28 & 56 & 16 & 96 & 4 & 0 & 14 & 14 & 5.33 & 48 & 4 & 0 \\
\hline F5 & 28 & 56 & 16 & 95 & 5 & 0 & 14 & 14 & 5.33 & 47.5 & 5 & 0 \\
\hline F5.3 & 28 & 56 & 16 & 94.7 & 5.3 & 0 & 14 & 14 & 5.33 & 47.35 & 5.3 & 0 \\
\hline \multirow{2}{*}{ O-F-N series } & \multicolumn{6}{|c|}{ Equivalent \% } & \multicolumn{6}{|c|}{ Atomic ratios } \\
\hline & $\mathrm{Ca}$ & $\mathrm{Si}$ & $\mathrm{Al}$ & $\mathrm{O}$ & $\mathrm{F}$ & $\mathrm{N}$ & $\mathrm{Ca}$ & $\mathrm{Si}$ & $\mathrm{Al}$ & $\mathrm{O}$ & $\mathrm{F}$ & $\mathrm{N}$ \\
\hline N0 & 28 & 56 & 16 & 95 & 5 & 0 & 14 & 14 & 5.33 & 47.5 & 5 & 0 \\
\hline N5 & 28 & 56 & 16 & 90 & 5 & 5 & 14 & 14 & 5.33 & 45 & 5 & 1.67 \\
\hline N10 & 28 & 56 & 16 & 85 & 5 & 10 & 14 & 14 & 5.33 & 42.5 & 5 & 3.33 \\
\hline N15 & 28 & 56 & 16 & 80 & 5 & 15 & 14 & 14 & 5.33 & 40 & 5 & 5 \\
\hline $\mathrm{N} 20$ & 28 & 56 & 16 & 75 & 5 & 20 & 14 & 14 & 5.33 & 37.5 & 5 & 6.67 \\
\hline $\mathrm{N} 25$ & 28 & 56 & 16 & 70 & 5 & 25 & 14 & 14 & 5.33 & 35 & 5 & 8.33 \\
\hline
\end{tabular}

Materials characterization. X-ray analysis was carried out using a Philips X'pert PRO Multi Purpose Diffractometer ( $\mathrm{Cu}-\mathrm{K} \alpha$ radiation) in order to confirm that the glasses were totally amorphous.

The bulk densities of samples of both series were measured by an Archimedean displacement technique using distilled water as the working fluid at a measured ambient temperature. The errors were calculated on more than three values of density. The standard normal distribution Student's $t$ was applied to find the $95 \%$ confidence limit coefficient [9]. These density values were used to calculate the molar volume (MV) of these glasses using the relationship:

$$
\mathrm{MV}=\left\{\sum_{\mathrm{i}}\left(\mathrm{x}_{\mathrm{i}} \mathrm{M}_{\mathrm{i}}\right)\right\} / \rho_{\text {glass }}
$$

where $x_{i}$ and $M_{i}$ are respectively the fraction and ionic mass of the ionic species $i$, and $\rho_{\text {glass }}$ is the measured glass density $\left[\mathrm{g} . \mathrm{cm}^{-3}\right]$. Glass Compactness values (C) were calculated according to the expression:

$$
\mathrm{C}=\left\{\sum_{\mathrm{i}}\left(\mathrm{x}_{\mathrm{i}} \mathrm{V}_{\mathrm{i}}\right)\right\} \mathrm{N} / \mathrm{MV}
$$

where $\mathrm{N}$ is Avogadro's number and Vi the volume of the ionic species calculated using ionic radii given by Shannon [10] for the various ions. The Young's moduli for the glasses were determined at room temperature from measurements of the longitudinal, $\mathrm{v}_{\mathrm{l}}$, and transverse, $\mathrm{v}_{\mathrm{t}}$, ultrasonic wave velocities with a better than $10^{-3}$ accuracy. These velocities are determined using two specially designed $10 \mathrm{MHz}$ piezoelectric transducers. The measurements are taken on parallel surface samples, each between 2.4 and $2.7 \mathrm{~mm}$ in width, using a Panametrics Pulse/Receiver Model 5072PR and a Hitachi VC6045 Digital Storage Oscilloscope. The longitudinal velocities $\left(\mathrm{v}_{1}\right)$ and the transverse velocities $\left(\mathrm{v}_{\mathrm{t}}\right)$ were determined using the expression:

$$
\mathrm{v}_{\mathrm{i}}=(2 \mathrm{~d}) / \mathrm{t}_{\mathrm{i}}
$$

where $d$ is the width of the sample, $t_{i}$ is the length of the period for longitudinal or transverse sine wave, $v_{i}$ is the resulting ultrasonic velocity in $\mathrm{m} / \mathrm{s}$. Young's Modulus (E) in GPa for each sample was calculated using the expression:

$$
\mathrm{E}=\rho\left(3 \mathrm{v}_{1}^{2}-4 \mathrm{v}_{\mathrm{t}}^{2}\right) /\left(\left(\mathrm{v}_{1} / \mathrm{v}_{\mathrm{t}}\right)^{2}-1\right)
$$

where $\rho$ is the density of the material. Shear Modulus (G) and Bulk Modulus (B) were then calculated using the following expressions:

$$
\begin{aligned}
& \mathrm{G}=\rho \mathrm{v}_{\mathrm{t}}{ }^{2} \\
& \mathrm{~B}=\mathrm{E} \mathrm{G} /\{3(3 \mathrm{G}-\mathrm{E})\}
\end{aligned}
$$


The hardness measurements were made using a LECO Microhardness indenter (M400-G1) with a $136^{\circ}$ Vickers diamond indenter. A load (P) of $0.3 \mathrm{Kg}$ was applied during 10 seconds. The indentation half-diagonals were measured using Buehler Imaging Enterprise Software (Buehler, USA). The indentation impression sizes and the Vickers indentation crack lengths were measured immediately after unloading. Only perfect indentation crack lengths, those with clearly symmetrical indentations and with symmetrical crack patterns, were used in the final calculations. A total of 10 perfect indentations were made at each load with the Vickers indenter. The microhardness was calculated using the following equation:

$$
\mathrm{H}_{\mathrm{v}}=1854.4 \mathrm{P} / \mathrm{d}^{2}
$$

where $\mathrm{H}_{\mathrm{v}}=$ Vickers Hardness $\left[\mathrm{Kg} / \mathrm{mm}^{2}\right], \mathrm{P}=$ applied load $[\mathrm{Kg}], \mathrm{d}=$ average length of indentation diagonals $[\mu \mathrm{m}]$.

Differential Thermal Analysis (DTA) was carried out using a Stanton Redcroft STA 1640 series, simultaneous thermogravimetric differential thermal analyser. $50 \mathrm{mg}$ glass powder samples were placed in a BN-lined platinum crucible to prevent any reaction between the platinum and the sample. Boron nitride is stable under a nitrogen pressure and does not induce any significant deviation of the temperature trace. Each sample was heated from 100 to $1300^{\circ} \mathrm{C}$ at a rate of $10^{\circ} \mathrm{C} / \mathrm{min}$ against an alumina reference and under a flowing nitrogen environment to prevent oxidation of the sample. Three different points within the glass transition range were determined from $\mathrm{Tg}_{\text {onset }}$, corresponding to the first endothermic change to $\mathrm{Tg}_{\text {offset }}$, which is the last point along the range and $\mathrm{Tg}$ is the mid-point of the transition range. Measurement errors in this study are \pm $2^{\circ} \mathrm{C}$. During the DTA experiment, the weight of the oxyfluoronitride samples was measured versus the temperature.

\section{Results and Discussion}

Glass formation and stability. XRD analyses of each of the fired glasses confirmed their amorphous nature. Transparent glasses were obtained for all the O-F series and the visual appearance suggested that they are homogenous. O-F-N glasses varied in colour from light grey and green to dark green as $\mathrm{O}$ was replaced by $\mathrm{N}$ (cf. Table 1) but they did not appear as homogeneous as the O-F series. From the thermogravimetric measurements, these glasses are stable with negligible weight loss up to $700^{\circ} \mathrm{C}$. For higher temperatures, at low nitrogen contents, there is weight loss which must be due to loss of fluorine from the O-F-N glasses, whereas eventually, as nitrogen increases, weight loss is converted into a weight gain due to the oxidation of the glass and the loss of some nitride species.

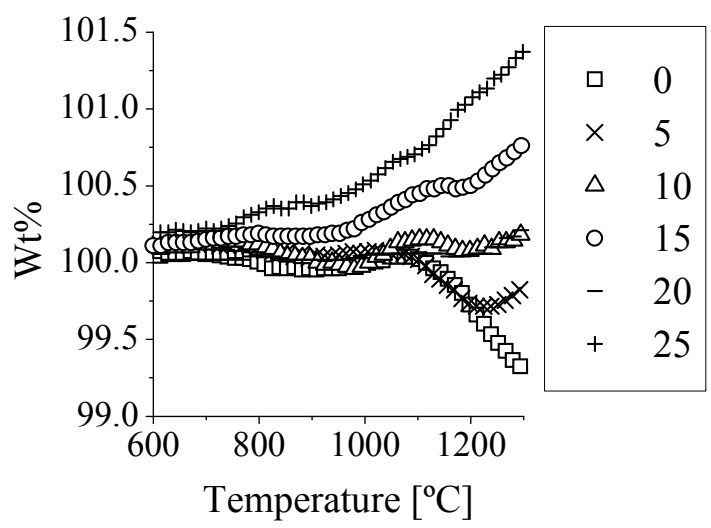

Fig. 1. Effect of nitrogen content on the weight measured during TGA/DTA experiments on the oxyfluoronitride glasses.

From the DTA experiments, the glass transition temperatures were determined. As can be seen from Fig. 2, glass transition offset temperature decreases roughly linearly with increasing fluorine 
content in the glass structure, whereas, there is a linear increase in $\mathrm{Tg}$ when nitrogen content increases. Similar behaviour has also been reported previously $[6,7,14]$. The Tg v. nitrogen gradient is similar to that observed by Dolekcekic [14]. The Tg v. F gradient is very large in comparison but comparable to the results of Griffin et al. [6, 7]. Those results, obtained on glasses with composition $\mathrm{Ca}_{22} \mathrm{Si}_{44} \mathrm{Al}_{33} \mathrm{O}_{100-\mathrm{x}} \mathrm{F}_{\mathrm{x}}$ are plotted in figure $2 \mathrm{a}$ and the slope observed is similar to the current results, even with different cation ratios. When fluorine is added, there is substitution of a bridging oxygen by a non-bridging fluorine and the removal of a network bridging anion. This means that the nitrogen anion contributes to the formation of the network and the fluorine tends to modify it.

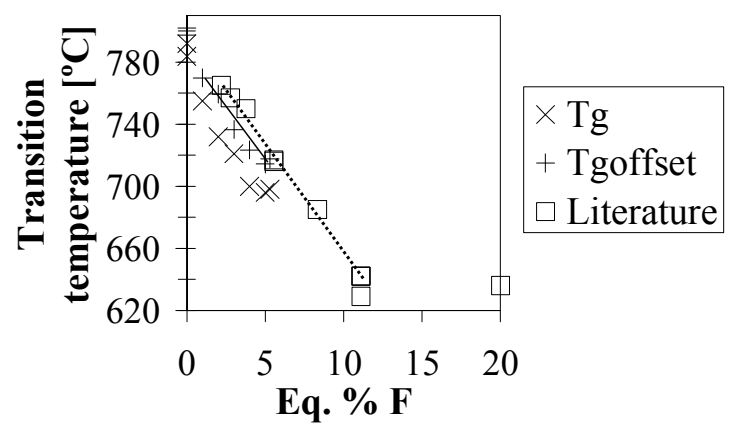

a)

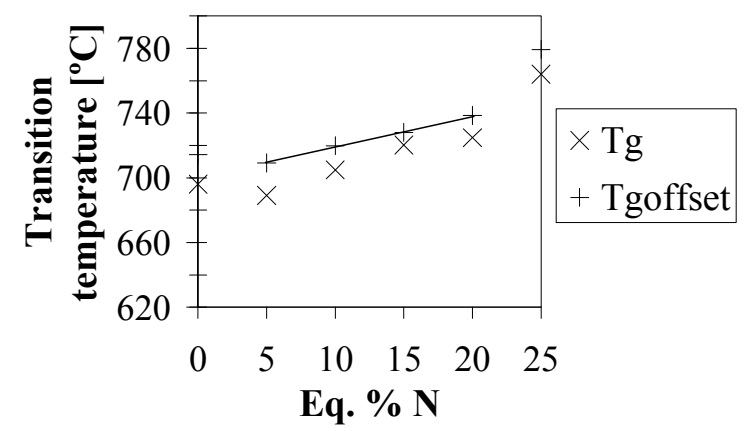

b)

Fig. 2. Effect of fluorine and nitrogen content on the glass transition temperature of (a) oxyfluoride and (b) oxyfluoronitride glasses.

Table 2. Properties of O-F glasses (annealed at Tg) and O-F-N glasses (annealed at Tg-50K)

\begin{tabular}{|c|c|c|c|c|c|c|c|}
\hline \multirow[t]{2}{*}{ O-F series } & \multicolumn{7}{|c|}{ Properties } \\
\hline & Colour & $\begin{array}{l}\text { Density } \\
{\left[\mathrm{g}^{-\mathrm{cm}^{-3}}\right]}\end{array}$ & $\begin{array}{c}\mathrm{MV} \\
{\left[\mathrm{cm}^{3} \cdot \mathrm{mole}^{-1}\right]}\end{array}$ & $\mathrm{C}$ & $\begin{array}{c}\mathrm{E} \\
{[\mathrm{GPa}]}\end{array}$ & $\begin{array}{c}\mathrm{G} \\
{[\mathrm{GPa}]}\end{array}$ & $\begin{array}{c}\mathrm{Hv} \\
{\left[\mathrm{Kg}^{\left.-\mathrm{mm}^{-2}\right]}\right.}\end{array}$ \\
\hline F0 & transparent & 2.829 & 8.05 & 0.5385 & 92.2 & 36.0 & 633 \\
\hline F1 & transparent & 2.841 & 8.02 & 0.5411 & 92.9 & 36.2 & 627 \\
\hline F2 & transparent & 2.837 & 8.03 & 0.5405 & 94.3 & 36.8 & 635 \\
\hline F4 & transparent & 2.837 & 8.02 & 0.5410 & 91.4 & 35.8 & 622 \\
\hline F5 & transparent & 2.823 & 8.06 & 0.5386 & 92.2 & 36.2 & 632 \\
\hline F5.3 & transparent & 2.832 & 8.03 & 0.5404 & 91.5 & 35.6 & 626 \\
\hline Experimental error & - & \pm 0.008 & \pm 0.02 & - & \pm 0.7 & \pm 0.9 & \pm 18 \\
\hline \multicolumn{8}{|l|}{ O-F-N series } \\
\hline N0 & transparent & 2.823 & 8.06 & 0.5386 & 92.2 & 36 & 632 \\
\hline N5 & $\begin{array}{l}\text { non-uniform grey } \\
\text { and light green }\end{array}$ & 2.856 & 7.98 & 0.5458 & 98.7 & 39 & 648 \\
\hline N10 & $\begin{array}{c}\text { non uniform dark } \\
\text { green }\end{array}$ & 2.863 & 7.97 & 0.5484 & 96.8 & 38 & 656 \\
\hline N15 & $\begin{array}{l}\text { non uniform dark } \\
\text { green }\end{array}$ & 2.873 & 7.95 & 0.5515 & 100.5 & 39 & 663 \\
\hline $\mathrm{N} 20$ & $\begin{array}{c}\text { non uniform grey } \\
\text { and green }\end{array}$ & 2.865 & 7.98 & 0.5511 & 99.0 & 39 & 663 \\
\hline Experimental error & & \pm 0.010 & \pm 0.03 & - & \pm 0.6 & \pm 2 & \pm 17 \\
\hline
\end{tabular}

Physical properties. Variations in glass density as a result of replacing oxygen by both fluorine and nitrogen are given in table 2 . Very little change in density is observed as oxygen is replaced by fluorine whereas a small increase in density is observed as oxygen is replaced by nitrogen as shown in previous studies [1-4].

The value of density for the $\mathrm{Ca}_{28} \mathrm{Si}_{56} \mathrm{Al}_{16} \mathrm{O}_{100}$ glass is lower than reported by Rouxel et al. [11] for the same composition glass but differences in the rate of cooling and the annealing temperature 
may result in density variations. $\mathrm{Ca}_{28} \mathrm{Si}_{56} \mathrm{Al}_{16} \mathrm{O}_{80} \mathrm{~N}_{15} \mathrm{~F}_{5}$ glass has a slightly lower density than $\mathrm{Ca}_{28} \mathrm{Si}_{56} \mathrm{Al}_{16} \mathrm{O}_{85} \mathrm{~N}_{15}[12,13]$ showing that $\mathrm{F}$ decreases the density although the differences in values are \pm 0.01-0.02, similar to the error range. Similar densities were also noted for $\mathrm{Ca}_{28} \mathrm{Si}_{56} \mathrm{Al}_{16} \mathrm{O}_{100}$ and $\mathrm{Ca}_{28} \mathrm{Si}_{56} \mathrm{Al}_{16} \mathrm{O}_{95} \mathrm{~F}_{5}$ glasses. It is to be noted that the changes in density may be due to the different anions of different coordination number and also changes in weight of the anions. The role of the different anions can be elucidated from the values of compactness in table 2. Fluorine anions have little effect on the network volume while nitrogen anions result in a more compact network.

The effect of fluorine and the nitrogen on Young's modulus and shear modulus for the oxyfluoride and oxyfluoronitride glasses are given in table 2 . The moduli decrease with increasing fluorine content and increase with increasing nitrogen content confirming previous results [2] for $\mathrm{Ca}$-Sialon glasses. The values of Young's modulus for the $\mathrm{Ca}_{28} \mathrm{Si}_{56} \mathrm{Al}_{56} \mathrm{O}_{100}$ glass varies with annealing treatment $[3,11]$ and reaches a maximum of $103.5 \mathrm{GPa}$ when annealed at $\mathrm{Tg}-50 \mathrm{~K}$. Similar values were found for a $\mathrm{Ca}_{28} \mathrm{Si}_{56} \mathrm{Al}_{16} \mathrm{O}_{85} \mathrm{~N}_{15}$ glass $[12,13]$ and the $\mathrm{Ca}_{28} \mathrm{Si}_{56} \mathrm{Al}_{16} \mathrm{O}_{80} \mathrm{~N}_{15} \mathrm{~F}_{5}$ glass. The addition of nitrogen to an oxyfluoride glass increases the mechanical properties.

Microhardness values for oxyfluoride and oxyfluoronitride glasses are shown in table 2. For oxyfluoride glasses, microhardness does not vary with fluorine content, taking into account the error range. For oxyfluoronitride glasses, microhardness increases with increasing nitrogen content as found previously for oxynitride glasses.

\section{Conclusions}

The addition of fluorine to alumino-silicate glasses has little effect on density, compactness, Young's modulus, shear modulus or microhardness with increasing fluorine content. Fluorine decreases the glass transition temperature to such an extent that this cannot be linked only to the replacement of oxygen by fluorine. Fluorine acts as a network "modifier" replacing a bridging oxygen ion by two non-bridging fluorine ions. On the contrary, nitrogen acts as a network "former" even in presence of fluorine with an increase in all properties with increasing nitrogen content.

\section{Acknowledgement}

The authors acknowledge Science Foundation Ireland for their financial support.

\section{References}

[1] R. A. L. Drew, S. Hampshire and K. H. Jack: Proc. Brit. Ceram. Soc. Vol. 31 (1981), p. 119

[2] S. Sakka, K. Kamiya and T. Yoko: J. Non-Cryst. Sol. Vol. 56 (1983), p. 147

[3] S. Hampshire, R. A. L. Drew and K. H. Jack: Phys. Chem. Glass. Vol. 26 (5) (1985), p. 182

[4] S. Hampshire: J. Non-Cryst. Sol. Vol. 316 (2003), p. 64

[5] M. J. Pomeroy, C. Mulcahy and S. Hampshire: J. Am. Ceram. Soc. Vol. 86 (2003), p. 458

[6] S. A. Griffin: PhD thesis - University of Limerick, Limerick (1996)

[7] R. Hill, D. Wood and M. Thomas: J. Mater. Sci. Vol. 34 (1999), p. 1767

[8] S. T. M. Shimada, H. Kiyono and K. J. D. MacKenzie: J. Euro. Ceram. Soc. Vol. 21 (2001), p. 2811

[9] J. Mandel: The Statistical Analysis of Experimental Data, ed. J. Wiley \& Sons (1967), New York (Interscience Publishers).

[10] R. D. Shannon: Acta Cryst. Vol. A.32 (1976), p. 751

[11] T. Rouxel, N. Dely, J.C. Sangleboeuf, S. Deriano, M. Lefloch, B. Beuneu and S. Hampshire: J. Am. Ceram. Soc. Vol. 88 (4) (2005), p. 889

[12] S. Deriano and T. Rouxel: Private Communication, University of Rennes 1, France.

[13] A. Clohessy: BSc thesis - University of Limerick: Limerick (2003)

[14] E. Dolekcekic: PhD thesis - University of Limerick: Limerick (2004) 


\section{Nitrides and Oxynitrides III}

10.4028/www.scientific.net/MSF.554

\section{Effect of Fluorine and Nitrogen Anions on Properties of Ca-Si-Al-O Glasses}

10.4028/www.scientific.net/MSF.554.31

\section{DOI References}

[2] S. Sakka, K. Kamiya and T. Yoko: J. Non-Cryst. Sol. Vol. 56 (1983), p. 147

doi:10.1016/0022-3093(83)90460-X

[4] S. Hampshire: J. Non-Cryst. Sol. Vol. 316 (2003), p. 64

doi:10.1016/S0022-3093(02)01938-5

[5] M. J. Pomeroy, C. Mulcahy and S. Hampshire: J. Am. Ceram. Soc. Vol. 86 (2003), p. 458

doi:10.1111/j.1151-2916.2003.tb03321.x

[6] S. A. Griffin: PhD thesis - University of Limerick, Limerick (1996)

doi:10.1080/0951839960090406

[7] R. Hill, D. Wood and M. Thomas: J. Mater. Sci. Vol. 34 (1999), p. 1767

doi:10.1023/A:1004550907134

[8] S. T. M. Shimada, H. Kiyono and K. J. D. MacKenzie: J. Euro. Ceram. Soc. Vol. 21 (2001), . 2811 doi:10.1149/1.1339866

[11] T. Rouxel, N. Dely, J.C. Sangleboeuf, S. Deriano, M. Lefloch, B. Beuneu and S. Hampshire: . Am. Ceram. Soc. Vol. 88 (4) (2005), p. 889

doi:10.1111/j.1551-2916.2005.00146.x

[14] E. Dolekcekic: PhD thesis - University of Limerick: Limerick (2004)

doi:10.4028/www.scientific.net/KEM.264-268.1863 